\title{
Towards the Creation of Healthier City Neighbourhoods for Marginalised Communities in South Africa: a Case Study of the South Durban Industrial Basin in the City of Durban
}

\author{
Ambrose A. Adebayo • Godfrey G. Musvoto • \\ P. Adebayo
}

Published online: 2 October 2012

(C) The Author(s) 2012. This article is published with open access at Springerlink.com

\begin{abstract}
This paper critically evaluates efforts to mitigate the adverse effects of pollution on residential communities that are located next to polluting chemical industries in the South Durban Basin area, in the city of Durban, South Africa. The economic agenda ignored socio-environmental imperatives as poor residential communities and polluting chemical industries were juxtaposed, which made the area prone to environmental and health hazards. Empirical research is conducted focusing on the relations among industry, the people, housing, health and the neighbourhood built environment. The paper notes that efforts to create healthier livable city neighbourhoods in Africa, and South Africa in particular, are hampered by the superimposition of industrial capitalism over social and environmental aspects of sustainable development. In this context, the paper argues marginalised neighbourhoods need to proactively articulate their environmental concerns in ways that foster the cooperation and remedial action of other stakeholders of urban governance especially the state and private sector.
\end{abstract}

Keywords Healthier city neighbourhoods · Marginalised communities

\section{Introduction}

The South Durban Basin, in the city of Durban, South Africa, was created in the 1970s by the pre-democratic apartheid government, with the main aim of employment creation

A. A. Adebayo $\cdot$ G. G. Musvoto $(\square) \cdot$ P. Adebayo

School of Architecture Planning and Housing, University of KwaZulu Natal, Durban, South Africa e-mail: godfreymusvoto@yahoo.co.uk

\footnotetext{
A. A. Adebayo

e-mail: adebayo@ukzn.ac.za

P. Adebayo

e-mail: adebayop@ukzn.ac.za
} 
through promoting industrial and economic efficiency. This goal of promoting economic growth and the creation of jobs in the 1970s led to the location of industry to the South of the Durban Bay, the integration of railways, shipping and industry in this location; the creation of African and Indian Housing schemes in the south in Lamontville and Merebank as sources of labour for industry and the necessity of undertaking reclamation, dredging and canalization to provide usable industrial land (Scott 2003). This spatial order meant that residential areas located next to polluting petrochemical industries face problems of environmental pollution. Petrochemical and chemical industries are concentrated in the SDB area, but at the same time, the area is home to approximately 100,000 people, some of them located dangerously close to chemical industries (Groundwork 2002a, b). Consequently the main problem facing residential communities in the SDB is atmospheric pollution due to chemicals such as sulphur dioxide $\left(\mathrm{SO}_{2}\right)$ being emitted by petrochemical industries. Thus, in the area, high prevalence of asthma has been reported. Ever since the 1970s when the SDB was founded, people living in the SDB have been fighting for a cleaner and healthier SDB. This fight however gained momentum with the advent of democracy in South Africa in 1994. This paper maps the progress to date in the quest for a healthier and livable $\mathrm{SDB}$, focusing on the relations and interactions among the main stakeholders in the quest of the marginalised community for a more livable and healthier environment.

\section{Healthier Cities: the International Context}

Internationally, concerns with the creation of livable healthier city neighbourhoods can be traced way back to the time of the early industrial city. Early industrial cities in Europe provided economic opportunities but the majority of economic migrants from rural areas, were unable to meet their needs for shelter and basic public services like water and waste disposal and treatment (Hall 2002). These early cities were characterised by sewerage contaminated water supplies, lack of proper arrangements for sewage disposal and overcrowded residential arrangements located next to polluting factories that were using carboniferous fuels. As a result nineteenth century industrial cities such as Manchester and Liverpool in England were susceptible to outbreaks of waterborne and other communicable diseases. Not surprisingly cholera and typhoid epidemics were rife especially among the poor city neighbourhoods; for example, killing 5,000 and 2,800 London and Glasgow residents, respectively, in 1832 (Pacione 2005). This led to concerted efforts focusing on ameliorating the spatial arrangements of the industrial city that had negative health consequences.

As the nineteenth century progressed to its end, two factors were important in shaping the structure of the city, namely the growth of urban reform movements and the rising affluence created by the new capitalist industrial economy (Thorns 2002). According to Thorns (2002), the rise of both the public health movement and epidemiology were central to drawing attention to the links between the occurrence of disease and spatial factors which in turn led to the realisation that diseases were related to such things as sanitation, clean water supply and proper drainage systems. Thus, the growth of medical knowledge, understanding that overcrowded insanitary urban areas had economic costs and the fear of social unrest, the importance of controlling market forces and private property rights in the interest of social well- 
being began to be appreciated (Cullingworth 1979, p. 15). Of significance, according to Thorns (2002), is the work of Booth on poverty, which linked it to income deprivation, occupation, residence and overcrowding. This assisted in the creation of a reformist agenda emphasising more regulation of urban development and improved physical and social conditions. Therefore, in the second half of the nineteenth century a series of legislations were passed with the aim of promoting public health.

Efforts towards the creation of healthier cities did not end with the abovementioned nineteenth century health reforms. They were reinforced by the rise to prominence of Ebenezer Howard's garden city movement which dominated the British and global planning at large until around the mid-twentieth century. The garden city concept is based on the premise of a neighbourhood that provides sound environmental quality through green belts surrounding residences, workplaces, parks and boulevards (Hall 2002). In Britain, the concept was highly influential in city planning as it culminated in the creation of garden cities such as Letchworth and Welwyn garden cities. It also influenced the planning of cities in the world in general.

The philosophy spread across the world to other developed countries such as Canada, the USA and developing countries such as Argentina and America. The USA, Canada and Argentina for instance also followed the British style garden city as they established garden cities such as Forest Hills Gardens, Krefeld Gartenstadt and Ciudad Jardin Lomas del Palomar, respectively. In South Africa, a country that was a colony of the British Empire, legislation such as the Public Health Act of 1917 were passed amid health scares caused by influenza outbreaks. Furthermore, a Garden Cities Trust was established in 1919 with the aim of providing housing with better social environments, consequently leading to the establishment of the Pinelands Garden city in Cape Town (Van der Merwe n.d.).

As such concerns with livable city neighbourhoods can be traced to the early industrial city. These efforts however did not end with the public health reforms that were made to the industrial city at the end of the nineteenth century. In fact, with the emergence of the sustainable development discourse in the twentieth century, the concern gained momentum. Sustainable development is conceptualised as: 'development that meets the needs of the present without compromising the ability of future generations to meet their needs' (World Commission on Environment and Development 1987, p. 8). 'Sustainability' is about the maintenance of health of the biosphere and the husbanding of key resources of air, water, land and mineral (Barton 1995).

Local governments have been placed at the forefront of championing sustainable development globally. They have vast influence on how urban-environment relationships develop and on how their cities interact with their hinterlands and with the wider global community, since effective local governance can make cities more competitive, more efficient and more attractive to investors and workers by promoting the sustainable development of the urban environment (The Cities Alliance 2007).

It is in this world policy context where focus is by and large on promoting sustainable development that the livable cities' movement was formalised in the developed countries. The movement started in the mid-1980s, as a brain child of Drs. Len Duhl and Trevor Hancock and was originally implemented through the Healthy Cities initiative spearheaded by the World Health Organization (Norris and Pittman 2000). According to Norris and Pittman (ibid) the aim initially was to improve the quality of life 
in 34 European cities but has ever since spread to more than 3,000 communities in more than 50 countries on every continent. At the heart of the healthy cities movement is the need to address community health problems such as unemployment, shortage of shelter, overcrowding, pollution and the diseases that might emanate there from such as cardiovascular diseases and Human Immuno Deficiency Virus (HIV). Therefore healthy livable cities entail neighbourhoods where people can live, play and work in harmony. As such, initiatives seek to balance economic health, environmental quality and social equity (Norris and Pittman 2000). Thus for healthy neighbourhoods to materialise they are supposed to be a shared goal among all the stakeholders of urban governance such as architects, city planners and community-based organisations, the business sector and local and central government and the inhabitants or people of varying social economic level for the development of healthier neighbourhoods within cities.

However, regardless of the environmental and quality of life emphasis of both the sustainable development discourse and the healthy cities movement, the creation of livable healthier neighbourhoods has seldom been met with success in the face of development that is biassed towards economic goals, especially in the developing countries. In most cases, the economic goals of transnational companies in collusion with African central governments have been espoused at the expense of social and environmental needs of mostly poor city residents. A classic case in Africa where there has been colossal failure in the creation of livable communities due the superimposition of economic goals is that of the Niger Delta in Nigeria. According to Ogunleye (2004), the environmental malaise in the Niger Delta is attributable to industrialisation, which saw huge refuse dumps next to residential areas resulting from urban consumerism and pollutants from the petrochemical industries.

When oil was discovered in the Niger Delta in 1958, there was a lot of excitement among the local communities as the people thought that positive transformation would be brought about with this discovery. However, as time progressed, the excitement turned into a nightmare, as the prospection of oil by transnational companies transformed their livelihoods for the worse, as it became the source of socioeconomic and environmental woes. This applies particularly to the two urban centres of Port Harcourt and Warri which serve as the operational bases of most multinational oil companies and indigenous service companies in the Niger Delta producing about $75 \%$ of Nigeria's petroleum which translates to over $90 \%$ of national government revenues (Ajao and Anurigwo 2002).

As a result of the persistence of these problems, community-based organisations have mushroomed in the Niger Delta, fighting for the social, health and environmental concerns of communities marginalised by economic development at their doorstep. However, little has been achieved as the Nigerian state seems to be colluding with the transnational companies in violating the people's socioeconomic and environmental rights. Jike (2004) argues that part of the reason has been the absence of appropriate legislation to regulate specifically the operations of transnational companies in the Niger Delta, regardless of the broader national constitution which guarantees everyone environmental rights. As such Moffat and Lindén (1995) argued that to achieve sustainable development in the Niger Delta, there is need for an appropriate policy framework, as well as specific projects and programmes, to deal with the failure to encourage markets to reflect the full social and environmental costs of goods and services, and lack of accountability and participation. 
The Niger Delta case in Nigeria demonstrates that without the cooperation of all stakeholders of urban governance especially the state and the business sector, the creation of livable city neighbourhoods will never materialise in Africa. This is also the case elsewhere in Africa where transnational mining companies have violated community environmental rights with African states playing a complicit role. The mining industry in Africa is little regulated which resulted in massive environmental pollution as in the case of copper and cobalt in Zaire, diamonds, gold, platinum and chromium in South Africa, uranium in Namibia and bauxite in Guinea where environmental pollution is a serious concern for mining towns (Clay 1994). The following section analyses the case of the South Durban Basin where residential communities were located next to polluting petrochemical industries in the name of economic efficiency during the apartheid era in South Africa. Since the creation of the South Durban Basin, communities exposed to industrial pollution have been fighting for cleaner and healthier neighbourhoods. With the advent of the democratic dispensation in South Africa in 1994, this fight gained momentum. In this empirical case study, relations among industry, the people, housing, health and the neighbourhood built environment is scrutinised so as to ascertain progress that has been made to date in the creation of livable neighbourhoods and also the reasons that hinder or foster the creation of healthier neighbourhoods.

\section{Methodology}

This paper uses the case study of the South Durban Industrial Basin in the city of Durban to assess efforts towards the creation of healthier city neighbourhoods for marginalised communities in South Africa. The South Durban Basin (SDB), in the city of Durban, is a typical case where the superimposition of the economic agenda of promoting industrial growth by the two main stakeholders of urban governance namely the state and the private sector ignored the basic need for a clean and healthy environment free from noxious gases emitted by chemical industries. As such, the SDB presents the opportunity to scrutinise and learn instructively the factors that promote or counter efforts to create healthier city neighbourhoods in areas with competing interests that oppose and promote positive social change concurrently.

The South Durban Basin (SDB) is the main manufacturing and industrial zone of the city of Durban, contributing $30 \%$ of the Durban's Gross Domestic Product and $10 \%$ of the manufacturing jobs in South Africa (Ethekwini Municipality Online 2010). It is an assortment of industrial and residential land use, located on the south of the Durban harbour. The area was created as a result of the joint interests of industry, Durban Town Council and the South African central government in the 1970s with the intention of promoting economic growth and employment creation in an efficient manner (Scott 2003). As such, there was integration of railways, shipping, industry and African and Indian residential areas in the areas of Lamontville, Merebank and Wentworth, as sources of labour for industry.

The industries integrated with residential areas in the SDB are mainly chemical and petrochemical industries. South African Petroleum Refinery (SAPREF) and Engen are the main petrochemical industries located in this area, although there are also other chemical industries such as Mondi, a paper manufacturing company. The biggest industry in this area is SAPREF an equally combined business enterprise 
between multinational companies Shell South Africa Energy and British Petroleum Southern Africa. SAPREF is the biggest crude oil refinery in Southern Africa, contributing $35 \%$ of South Africa's refinery capacity, which is roughly 180,000 barrels of crude oil per day or 8.5 million tons per year (South African Petroleum Refinery 2010).

However, in as much as the South Durban Basin is a compact, mixed land use urban residential neighbourhood, where people are conveniently located next to job opportunities, the problem of atmospheric pollution from chemical and petrochemical industries facing residential communities juxtaposed with the industries overshadows this gain. The main pollutant emitted by refineries is sulphur dioxide $\left(\mathrm{SO}_{2}\right)$. Although there are regulations on the amount of $\mathrm{SO}_{2}$ that refineries can emit a day, the refineries more often than not violate these regulations. For instance the Air Pollution Prevention Act of 1965 (APPA) permits SAPREF to emit $59 \mathrm{t}$ of $\mathrm{SO}_{2}$ a day, but in 2000 , they admitted they had been underreporting by as much as $12 \mathrm{t} /$ day for the past 5 years, claiming an error in calculation (Groundwork 2002a, b). Government's reaction was muted and imposed no penalty. Thus, not surprisingly, the South Durban Basin is reported to have the highest concentrations of encircling $\mathrm{SO}_{2}$ in South Africa, in addition to which there is noise pollution, intrusion of heavy vehicles in residential areas, frequent leakages of oil pipes and flaring of refineries and contaminated soils and water (Scott et al. 2002). The spatial arrangements in the SDB are such that emissions from industrial chemical processing activities can clearly be seen lingering over juxtaposed residences during the day (Fig. 1).

Consequently, the people living in the SDB suffer health problems that are related to the breathing of air with abnormal concentrations of $\mathrm{SO}_{2}$. Groundwork $(2002 \mathrm{a}, \mathrm{b})$ points that in South Durban, community members have consistently complained of high levels of cancer and respiratory illnesses. Studies conducted within the community concluded that respiratory illnesses were clearly elevated compared to other areas outside of South Durban. A medical researcher suggests a leukaemia rate 24 times the national average (Carnie 2001; cited in Groundwork 2002a, b). The Universities of Natal and Michigan and the Natal Technikon also conducted a health study at the Settlers Primary School, situated between two SDB refineries and they discovered that $53.5 \%$ of students suffered from some type of asthma, a prevalence higher than any

Fig. 1 Polluting refinery in the SDB

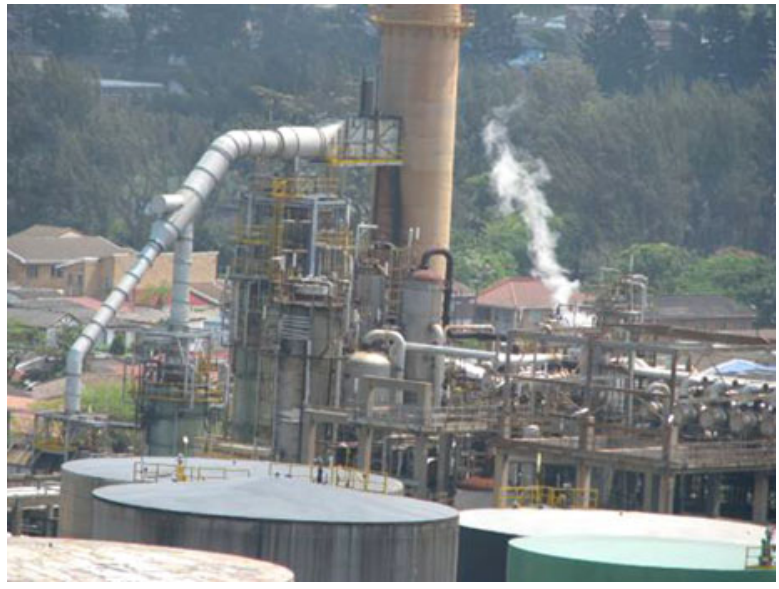


comparable findings reported in literature (Groundwork 2002a, b). A study conducted by Nriagu et al. (1999) also points to self-reported prevalence rates for wheezing (37$40 \%$ ) and attacks of shortness of breath with wheeze (16-28\%) in the SDB, which were far higher than those for doctor-diagnosed asthma and common co-occurrence.

These pollution-related health problems occur in a context where the housing constructed to house workers by the state when the SDB was established were far from being satisfactory. Of concern are overcrowded male single sex compounds (hostels) that were meant to house male migrant labourers. There are approximately five hostels in the SDB. Other residential typologies are mainly free-standing fourroomed overcrowded family compounds. As such, the creation of healthier neighbourhoods in the SDB is not only limited to the reduction of pollution from petrochemical industries, but also to improving the quality of the residential compounds in the area.

Ever since, the SDB was established during the apartheid era in South Africa, residential communities located next to polluting chemical industries have been fighting for livable healthier and cleaner neighbourhoods. There are hostile relations pitting the community on one side and industry and local government on the other. The communities accuse the industry and government of overemphasising economic interests at the expense of their environmental and health needs. The government is accused by the community of not doing enough to force industries to comply with environmental regulations. With the dawn of the democratic dispensation in 1994 in South Africa, the fight for a healthier livable environment by the SDB community gained momentum. This was in view of the introduction of the new democratic Constitution which made socioeconomic and environmental rights an imperative. Furthermore the Constitution made provisions for freedom of association, paving the way for community activism. As such, since 1994, there have been concerted efforts to improve the quality of residential environment in the SDB from all the stakeholders in the SDB, namely the industries, government and the community. These efforts ranged from social responsibility programmes engaging in projects such as AIDS awareness campaigns by the industry, hostel upgrading projects by the government and also protest action by community members as a way of forcing industries to comply with environmental regulations. As such, using the empirical case study of the SDB, this paper aims to ascertain progress to date in the efforts to create healthier, livable and sustainable South Durban Industrial Basin and also to assess relations among stakeholders of urban governance in the creation of healthier neighbourhoods.

\section{Data Sources}

The paper uses both primary and secondary data obtained from the main stakeholders of urban governance in the SDB whose roles and actions have an effect on the creation of a healthier livable SDB. These are namely SAPREF, SDCEA and South Durban Basin Area-Based Management (SDB ABM). SAPREF represents the interests of all the chemical and petrochemical industries in the SDB as it is the largest chemical industry in the SDB and Southern Africa. It started operations in 1963 and since then it has been the biggest emitter of $\mathrm{SO}_{2}$ in the SDB. SDCEA as the biggest 
community-based organisations (CBO) operating in the SDB was formed in 1995 a year after the end of apartheid in South Africa represents the community's views and experiences in its quest for a more livable neighbourhood. It is a coalition of members of several communities whose aim is to ensure sustainable development in the SDB by ensuring the environmental health of the human and natural environment in close proximity to clean industry. The SDB ABM is the local government in the SDB and has a mission to restore business confidence, consolidate existing infrastructure and stimulate new development, facilitate renewed socioeconomic investment and to improve quality of life by solving environmental problems. To obtain primary data semi-structured face to face interviews were conducted with these stakeholders with the view of mainly soliciting their views on the challenges facing the creation of healthier livable neighbourhoods in the SDB, measures taken to date and also factors positively and negatively impacting these efforts. Primary data were complemented by secondary data mostly from the websites of these main stakeholders with specific focus on their visions and missions and also activities relating to the promotion of environmental integrity in the SDB.

\section{Analysis and Discussion}

The analysis of both primary and secondary data on the pollution dispute in the SDB obtained from the different role players was based on establishing coalitions among different stakeholders around the various sub-themes of the efforts to create a healthier and more livable neighbourhood. Coalitions were specifically sought around perceptions on the condition of the SDB in relation to it being a livable and healthy neighbourhood, actions taken to date and also success and failure factors in the quest to make the SDB a more healthier and livable neighbourhood.

One of the key finding from primary and secondary information that came from all the role players in the creation of a healthier and livable SDB is that the location of residential areas next to polluting chemical industries seriously marginalises community environmental rights. It was noted that this is evidenced by the violation of environmental regulations by chemical industries notably through the emission of noxious gases such as sulphur dioxide to extents that compromises the health well-being of the residential communities. All the stakeholders in the SDB highlighted that to a large extent the creation of healthier and more livable neighbourhoods has been hampered by the superimposition of economic goals of industrial production at the expense of community environmental rights. As such, there was consensus from all stakeholders in the SDB that pollution from chemical industries is a problem.

This scenario in the SDB, according to most stakeholders (SDCEA, SDB ABM and SDCEA's affiliate organisations) has been perpetuated by the fact that the government (Durban metropolitan municipality) is complicit with the industrial activity. It was noted that efforts to create a healthier SDB are also negatively affected by the government, which is complicit with the industry in promoting the economic agenda of both parties and paying less attention to the environmental needs of the communities affected by pollution from industry. The SDCEA chairperson clearly pointed out that the government is conniving with the industry as it is not imposing hefty fines on the industry for the violations of environmental regulations. This was 
also voiced by some of the SDCEA's affiliate organisations that pointed out that, 'the problem of pollution from industries is realistic, but the responses that we are getting from the government seem to be monetary'. The Social Programs Manager of the SDB ABM also pointed out that the industries are the city's major ratepayers so the council treats them with velvet gloves by imposing light penalties for violating air quality regulations. As such, the superimposition of economic goals and the complicit role of the government in neglecting the socio-environmental sustainability goals is a major hindrance in the creation of a healthier and livable SDB city neighbourhood.

However, in as much as the industrial pollution from chemical industries and the complicit role of government in the SDB was blamed for the compromised health and livability status of the SDB, other factors were highlighted as well. There were coalitions in the SDB from all the role players, except SDCEA to the effect that on top of pollution from chemical industries, the creation of healthier livable neighbourhoods in the SDB is also negatively affected by the problem of endemic and chronic poverty among residents. SAPREF, SDCEA's affiliate organisations and also the SDB ABM argued that in as much as pollution from industry is a problem, there was also an urgent need to tackle poverty if the neighbourhood was to be livable and healthier in the true sense. High rates of unemployment that translated into problems of crime and drug abuse were pointed as key manifestations of poverty. As such, one notes that for marginalised communities in areas with competing interests, although there might be one central issue challenging their health and livability status, such as pollution in the case of the SDB, other community needs have to be addressed as well. The fact that almost all stakeholders in the pollution dispute in the SDB agreed to the fact that there are other problems besides pollution is evidence that livable neighbourhoods are made up of a wide array of factors.

Furthermore, in addition to the fact that poverty also hinders the creation of a healthier and livable SDB, the role of the community marginalised by and large by pollution from chemical industries was also highlighted as making matters worse. This is so as role players laid emphasis on the fact that the SDB community was not taking responsibility for creating a healthier and more livable SDB by taking care of micro issues affecting their everyday lives. There was by and large consensus to the effect that the environmentally marginalised community of the SDB also needs to take care of the other aspects of a livable neighbourhood within its means and capacity. As such, while there was agreement from all parties that environmental pollution caused by chemical industries is the main hindrance to the goal of creating healthier livable neighbourhoods in the SDB, lack of cooperation from the community itself was also noted. Some of SDCEA's affiliate organisations highlighted the fact that among the SDB community members, there was lack of clear understanding of the key underlying principles of personal hygiene and its importance to the health and livability of neighbourhoods. The Social Programs Manager of the SDB ABM pointed to a health study that was conducted in the SDB that highlights poor hygiene as a problem in the area. SAPREF's Environmental Manager, also noted that, 'mere existence causes pollution', taking the argument further. This implies that chemical industries in the SDB are only but one source of pollution. Therefore in as much as the industry has to play its part in creating a livable neighbourhood, the community members themselves also have to play their part in personal and neighbourhood hygiene. This again reinforces the argument that creating livable neighbourhoods is a 
responsibility of all parties in urban governance and is also a function of a wide array of factors. Although in contested urban landscapes where communities are marginalised, there might be grand issues negatively affecting their livability status, such as environmental pollution in the case of the SDB, marginalised communities must also take care of issues of affecting their personal health and the livability of their neighbourhoods within their reach and capabilities.

It should be noted however that from both primary and secondary engagement with the main role players in the creation of a healthier and livable SDB it was noted that ever since the dawn of democracy in South Africa in 1994, there has been remarkable and noticeable progress in curbing environmental pollution in the SDB. A number of concrete efforts and measures have since been taken in the SDB to address industrial pollution the key factor in marginalising the community's quest for a healthier and more livable neighbourhood. For instance, in 2000, SDB Multi-Point Plan (SDB-MPP) was established for air pollution management at the local government level in the Durban city. R30 million was invested in the establishment of 14 monitoring stations in the SDB, along with two meteorological stations that were established. The success of the project is based on the fact that this plan has been successful in reducing $\mathrm{SO}_{2}$ emissions by $45 \%$ (Van Alstine 2007). On the other hand, SAPREF also achieved International Standards Organisation (ISO) 14001, volunteered to be the subject of a Shell Social Performance Review in 2002, started publishing Annual Environmental and Social Performance reports in 2001, enlarged the Health Safety and Environmental department in 2002 Therefore, democracy at a national level is crucial to ensuring the interests of marginalised communities in relation to creation of healthier and more livable neighbourhoods. During the apartheid era in South Africa, racial discrimination meant that the state relatively turned a blind eye to the creation of livable neighbourhoods for some racial groups. With the dawn of democracy, equal rights were guaranteed for all by the democratic South African constitution. In line with this democratic political development at a national level, measures also started being put in place in the SDB to create a healthier and more livable neighbourhood.

The case of the SDB also shows that CBOs are central in promoting healthier and livable neighbourhoods for marginalised communities. SDCEA as a CBO advocating for a cleaner and healthier environment has managed to raise awareness about the pollution and also to lobby government and industry to address the problem. Some measures were put in place by polluting industries to reduce the problem of pollution in the SDB because of the activities of SDCEA that focus on promoting the agenda of a cleaner SDB since 1995. For example, SAPREF in 1998 hired a communications manager to engage with SDCEA specifically and other community organisations in general, in a bid to find solutions to environmental problems in the SDB. There are a number of innovative practices that SDCEA engaged in as a way compelling the government and industry to proactively participate in the creation of a healthier and more livable SDB. One of the main measures that SDCEA employed was buying shares from SAPREF the biggest chemical industry in the SDB so that it can voice community health concerns posed by SAPREF from within the company ranks during annual general meetings. In 2004, Desmond D'Sa and Adriel Soeker as representatives of the SDB community attended Shell's annual general meeting in the UK where they raised concern about the way SAPREF (subsidiary of Shell) is 
compromising community environmental health needs in South Africa. The rationale according to SDCEA is gaining sympathy for the SDB community at a global level. Another practice that SDCEA engages in order to promote community environmental needs compromised by polluting industry is using the courts of law to censor industrial activity in the SDB that compromise community health well-being. For example, in 2002, SDCEA successfully appealed in the Durban high court against the decision by Mondi paper manufacturing company to expand its industrial plant without conducting a full environmental impact assessment. Furthermore, in order to strengthen its cause for creating a healthier and more livable SDB, through learning from cross-reference and comparisons, SDCEA forges alliances with international environmental justice organisations such as Denmark's Natufrednings forening. SDCEA also makes presentations at local and international environmental forums on the environmental concerns of the SDB community. SDCEA's chairperson noted that:

SDCEA presents everywhere how they are killing our children and they cannot deny that. When SDCEA puts all this in the media, they cannot deny that they are because they have not sued SDCEA. SDCEA deals with them in a professional manner since everything they present or release to the press is factual evidence.

It is also important to take note of the way SDCEA has constructed the problem of pollution in the SDB in order force the cooperation of all stakeholders in the creation of a livable neighbourhood. SDCEA writes stories about the pollution problems in the SDB with sensational headlines that they publish both in the local and international media. The stories that SDCEA writes are full of literary devices, such similes and hyperbole that are meant to vilify the industry, and thus strengthen their viewpoint. There is a positive correlation between media use and political engagement (Kock n.d.). Thus by writing sensational stories on the problem of pollution in the SDB in the media, SDCEA has managed to get a lot of political attention which culminated into tangible remedial action such as the establishment of monitoring stations noted above.

\section{Conclusions}

From the paper, it can be discerned that the goal of creating healthier and more livable city neighbourhoods is widely acknowledged worldwide in line with the discourse of sustainable development. However in the developing world, particularly in Africa, where the private sector colludes with the state to promote the industrial goal of economic growth at the expense of community environmental needs, creation of healthier and more livable neighbourhoods has been compromised. This is by and large the case in both the Niger Delta and the South Durban Basin in Nigeria and South Africa respectively where regardless of constitutional assurances of environmental rights for all, pollution from industrial activity has by and large marginalised community health needs. The empirical study of the South Durban Basin has demonstrated that in areas pitting the economic interests of the industry and community health needs there is one main grand issue compromising the creation of healthier 
and livable communities, such as industrial pollution for instance. However, there are other factors at play that influence the ways and extent communities can be further marginalised. In the South Durban Basin it was emphasised that besides pollution, issues of poverty and lack of enough knowledge about personal hygiene among residents also further compromised efforts to create a healthier and more livable South Durban Basin on top of environmental pollutants coming from chemical industries. From this end, one notes that besides grand issues, such as structural issues of pollution from industry negatively affecting efforts to create healthier neighbourhoods for the marginalised, communities in question themselves need to address micro issues within their reach that add up to the sum-total of livable cities. Pertinently also is the fact that for neighbourhoods marginalised by the activities of the private sector in collusion with the state, there is need to develop a proactive and innovative civil society operating from the grass roots to counter hegemonic tendencies of the relatively more powerful stakeholders of urban governance. The SDCEA $\mathrm{CBO}$ uses hyperbole and similes to denigrate the activity of industry in the SDB in order to sanctify its cause for a healthier more livable neighbourhood. Through this innovative measure, among many others, SDCEA has by and large managed to compel the business and the state to redress the pollution problem in the SDB.

Open Access This article is distributed under the terms of the Creative Commons Attribution License which permits any use, distribution, and reproduction in any medium, provided the original author(s) and the source are credited.

\section{References}

Ajao, E. A., \& Anurigwo, S. (2002). Land-based sources of pollution in the Niger Delta, Nigeria. Ambio, $31,442-445$.

Barton, H. (1995). Sustainable settlements: a guide for planners, designers and developers. Bristol: University of the West England.

Cities Alliance (2007) Liveable cities the benefits of urban environmental planning: a Cities Alliance Study on Good Practices and Useful Tools. Washington, http://www.citiesalliance.org/index.html. Accessed 10 May 2011

Clay, R. (1994). A continent in chaos: Africa's environmental issues. Environmental Health Perspectives, $102,1018-1023$.

Cullingworth, J. B. (1979). Town and country planning in Britain. Boston: George Allen and Unwin.

Ethekwini Municipality Online (2010) The official site of the city of Durban. Durban, www.durban.gov.za. Accessed 10 June 2010.

Groundwork (2002a). Contested path to self-regulation. Partners in Pollution Voluntary Agreements and Corporate Greenwash. Pietermaritzburg.

Groundwork (2002b). Oil in the hood. People on Petrochemical Fence-Line, Pietermaritzburg.

Hall, P. G. (2002). Urban and regional planning. New York: Routledge.

Van der Merwe, D (n.d.). History of Pinelands South Africa' first garden city. http://sitesgoogle.com/ dvdmerwe/historyofpinelands. Accessed 10 June 2010.

Jike, V. T. (2004). Environmental degradation, social disequilibrium, and the dilemma of sustainable development in the Niger-Delta of Nigeria. Journal of Black Studies, 34, 686-701.

Kock, C. (n.d.). Rehetoric in Media Studies: The Voice of Constructive Criticism. Plenary Session IV. Rhetorics in Media Studies-Media Studies in Rhetorics. http:/www.nordicom.gu.se/common/publ-pdf/ 157_103-110.pdf. Acessed 12 October 2007 
Moffat, D., \& Lindén, O. (1995). Perception and reality: assessing priorities for sustainable development in the Niger River Delta. Ambio, 24, 527-538.

Norris, N., \& Pittman, M. (2000). The healthy communities movement and the coalition for healthier cities and communities. Public Health Reports, 115, 118-124.

Nriagu, J., Robins, T., Gary, L., Liggans, G., Davila, R., Supuwood, K., et al. (1999). Prevalence of asthma and respiratory symptoms in South-Central Durban, South Africa. European Journal of Epidemiology, $15,747-755$.

Ogunleye, F. (2004). Environmental sustainability in Nigeria: the "awareness" imperative. African Studies Association, 31, 41-52.

Pacione, M. (2005). Urban geography: a global perspective. Landon: Routledge.

Scott, D. (2003). Creative destruction: early modernist planning in the South Durban Industrial Zone, South Africa. Journal of Southern African Studies, 29, 235-259.

Scott, D., Oelofse, C., Guy, C. (2002). Double trouble: environmental injustice in South Durban. Agenda, No. 52, Sustainable Development: An Oxymoron?, 50-57.

South African Petroleum Refinery (2010). Welcome to SAPREF. Durban, www.spref.com. Accessed 10 June 2010.

Thorns, D. C. (2002). The transformation of cities: urban theory and urban life. New York: Macmillan.

Van Alstine, J. (2007). Institutions for the environmental governance of multinational corporations: the SAPREF oil refinery in Durban, South Africa. Amsterdam, http://www.2007amsterdamconference.org. Accessed 12 Oct 2007.

World Commission on Environment and Development (1987). Report of the World Commission on Environment and Development: our common future. www.un-documents.net/wced-ocf.htm. Accessed 10 June 2010. 